\title{
COPYRIGHT LAW REFORM: SOME ACHIEVABLE GOALS?
}

\section{Hector L MacQueen ${ }^{*}$}

in Fiona Macmillan (eds) N ew D irections in Copyright L aw, V olume 4 (Edward Elgar, 2007) pp.55-81

\section{A. INTRODUCTION: THE NEED FOR REFORM}

Copyright law reform is in the air. A European Commission staff working paper on the review of EU legislation on Copyright and Related Rights, issued for consultation in July $2004,{ }^{1}$ assesses, in particular, whether any inconsistencies between the different Directives hamper the operation of EU copyright law or damage the balance between rights holders' interests, those of users and consumers and those of the European economy as a whole. The working paper concludes that there is no need for root and branch revision of the existing Directives but that fine-tuning is necessary to ensure that definitions - for example of reproduction right - are consistent. Similar updating is thought necessary with respect to the exceptions and limitations set out in the different Directives. The working paper also assesses whether further legislative or other action is needed to ensure the Internal Market functions properly, and concludes that the immediate need for action may be limited to achieving a "level playing field" on the criteria used to determine the beneficiaries of protection in the field

* Director, AHRC Research Centre for Studies in Intellectual Property and Technology Law, and Professor of Private Law, University of Edinburgh. All website references in this paper were last checked on 15 November 2005. ${ }^{1}$ Commission Staff Working Paper on the review of the EC legal framework in the field of copyright and related rights, SEC(2004) 995 (http://europa.eu.int/comm/internal_market/copyright/review/consultation_en.htm) 
of related rights. It may be significant, however, that the Consultation Paper appears to envisage a future 'Copyright Code' for Europe, in which the present piecemeal collection of Directives enacted at various times since 1991 will be consolidated and, presumably, the gaps between them filled: "the Commission," we are told, "is working towards its objective of completing the consolidation of the acquis communautaire in its most authoritative form - codification". ${ }^{2}$ The process will apparently involve first the Software, Rental Right and Term Directives.

In the United Kingdom, the Labour Party's manifesto for the 2005 general election included the following commitment:

Copyright in a digital age: We will modernise copyright and other forms of protection of intellectual property rights so that they are appropriate for the digital age. We will use our Presidency of the EU to look at how to ensure content creators can protect their innovations in a digital age. Piracy is a growing threat and we will work with industry to protect against it. $^{3}$

The reference here to the Presidency of the European Union, to be held by Britain in the second half of 2005 , is especially significant against the background of the Commission's consultation in 2004. The emphasis falls on protection of

\footnotetext{
${ }^{2}$ Ibid, para 1.3 (last internal para).

${ }^{3}$ Britain Forward Not Back: The Labour Party Manifesto 2005, accessible at http://www.labour.org.uk/fileadmin/manifesto_13042005_a3/flash/manifesto_200 5.swf (p. 95).
} 
intellectual property rights against the "threat" of "piracy"; the Labour Party reform agenda is clearly one in which strengthening intellectual property is the way to respond to "the digital age".

After Labour had been returned to government at the election in May 2005, James Purnell, the new Minister of Creative Industries and Tourism at the Department of Culture Media and Sport (DCMS), said the following in a speech delivered on 16 June:

I can announce today that DTI and DCMS will set up a joint project to implement our manifesto commitment [i.e. the one just quoted] chaired by Lord Sainsbury and myself. We will examine in the first place what issues need to be addressed, including the key issue of Digital Rights Management and the interoperability of new technologies. Obviously the primary role is for industry, which is why we have asked the Creative Industries IP Forum to advise us on this. ${ }^{4}$

We may note here that the Creative Industries Forum on Intellectual Property is a cross-Government body (including the devolved administrations and also industry representatives), set up by DCMS in July 2004. The Forum's task was to consider how best to meet the "opportunities and threats that rapid

\footnotetext{
${ }^{4}$ Accessible on the DCMS website at http://www.culture.gov.uk/global/press_notices/archive_2005/purnell_creative_in ds_speech.htm.
} 
technological developments are generating for the UK's Creative Industries sector". ${ }^{5}$

Purnell's speech was non-committal on the shape reform might take, but he did add this:

To attract creative companies, they need to know that we have an IP regime that will allow them to make returns on their creativity and to invest in innovation. Bands like Coldplay will make enough money for their company to help them discover around 50 to 100 bands. At the same time, an information rich society needs an easy exchange of ideas - after all, creativity often comes from collaboration, from putting existing ideas together in new ways. So, we need an IP framework that balances the needs of consumers, creators and businesses.

The Minister's first and foremost point is, then, the need to produce an intellectual property law which supports economic returns on creativity and innovation, from which, it is argued, investment in more creativity and innovation will be generated - a virtuous circle indeed. While the speech does refer at the end of the quoted passage to the need for balance in intellectual property rights, the needs of industry, particularly the creative industries, are emphasised more -

\footnotetext{
${ }^{5}$ See UK Patent Office press release 19 July 2004 http://www.patent.gov.uk/media/pressrelease/2004/1907.htm.
} 
"obviously" the "primary role" in developing proposals for reform lies with industry.

Further, the Creative Industries IP Forum in which this primary role was to be discharged is a body the membership of which is dominated by representatives of the industries concerned. The Consumers Association is included, but whether that body can adequately represent the interests of all nonindustry stakeholders with regard to the output of the creative industries education and research interests, for example - is at least debatable. Neither the publicly available minutes of meetings of the Forum, nor the reports of its working groups published in October 2005, suggest that such interests have featured prominently - or indeed at all - in its deliberations. ${ }^{6}$ The concerns of consumers, or users of intellectual property, also appear as little more than an afterthought in Purnell's speech, and really only in so far as they are potential creators themselves.

Amongst the many developments which have thus brought copyright reform to the fore in the UK and Europe may be included the following:

\footnotetext{
${ }^{6}$ The recommendations of the Creative Industries IP Forum working groups - a charter against online infringement and a stiffening of law and sentencing in relation to "IP crime" - and the Government's cautiously non-committal response thereto are available, along with two sets of Forum meeting minutes, at http://www.culture.gov.uk/creative_industries/ip_forum.htm.
} 
- File-sharing through unlicensed peer-to-peer networks, especially with regard to sound recordings, but also in relation to computer software and games, and increasingly in relation to films as well. ${ }^{7}$

- Sound recording industry pressure to replace the term for the protection of sound recordings (currently 50 years from release) with a term the same as that in the USA (i.e. 95 years from the year of first publication) ${ }^{8}$

- Open access, or author-pays, publishing of scholarly and scientific journals (that is, authors or, more usually, their research funders pay to publish their articles in a journal; publishers send the articles out for peer review; articles of a sufficiently high standard are edited and published; and the journal is disseminated free of charge, primarily online). First recommended by the Wellcome Trust, a leading funder of research, in $2003,{ }^{9}$ and later supported in a Report of the House of Commons Science and Technology Select

\footnotetext{
${ }^{7}$ See C Waelde and H MacQueen, 'From Entertainment to Education: the Scope of Copyright', [2004] Intellectual Property Quarterly 259, reviewing the current debate down to April 2004. Since then the major developments are the growth of licensed downloading sites, increased numbers of actions against individual downloaders, and the decisions against the operators of unlicensed file-sharing networks made by the US Supreme Court in MGM v Grokster 545 US 000 (2005), and the Federal Court of Australia in Universal Music Australia Pty Ltd $v$ Sharman License Holdings Ltd [2005] FCA 1242.

${ }^{8}$ See BBC News Online 26 July 2004, http://news.bbc.co.uk/1/hi/entertainment/music/3925975.stm; 10 August 2004, http://news.bbc.co.uk/1/hi/entertainment/music/3547788.stm

${ }^{9}$ Wellcome Trust, An Economic Analysis of Scientific Research Publishing (2003); Costs and Business Models in Scientific Research Publishing (2004), both accessible at http://www.wellcome.ac.uk/doc_WTD002766.html.
} 
Committee published in July $2004,{ }^{10}$ the idea was thereafter rather negatively received by government. ${ }^{11}$ Since then, however, Research Councils UK, the collective body of the eight councils providing public funding for research in Britain, has moved towards making it mandatory for research papers arising from Councilfunded work to be deposited in openly available repositories. ${ }^{12}$

- The establishment of Creative Commons UK (building on a US model), with the aim of developing forms of licence under which copyright is retained but users are given advance permission to copy and distribute the work for their own purposes so long as due credit is given to the original work; this being, it is argued, the most appropriate way to support and encourage creativity and innovation in the on-line and digital environments. ${ }^{13}$

${ }^{10}$ Scientific Publications: Free for All? (Tenth Report 2003-2004, HC 399), accessible at http://www.publications.parliament.uk/pa/cm200304/cmselect/cmsctech/399/399 02.htm.

${ }^{11}$ See http://www.publications.parliament.uk/pa/cm200304/cmselect/cmsctech/1200/12 0006.htm\#a1. For the Committee's response, a further Report published in November 2004, see Scientific Publications: Free for All? - the Government's Response (Fourteenth Report 2003-2004, HC 1200) http://www.publications.parliament.uk/pa/cm200304/cmselect/cmsctech/1200/12 0002.htm.

${ }^{12}$ See RCUK Position Statement on Access to Research Outputs (June 2005), accessible at http://www.rcuk.ac.uk/access/index.asp. For a further press release on the subject in September 2005, see http://www.rcuk.ac.uk/press/20050921rcuk.asp.

${ }^{13}$ See http://creativecommons.org/projects/international/uk/; there is also a site for Scotland (http://creativecommons.org/worldwide/scotland/). 
- The publication of the Adelphi Charter on creativity, innovation and intellectual property in October $2005,{ }^{14}$ calling upon governments to maintain a balance between public domain and private right, and between competition and monopoly, with regard to intellectual property rights in general; to ensure in particular that the copyright term is limited in time and does not extend beyond what is proportionate and necessary; and to facilitate a wide range of policies to stimulate access and innovation, including nonproprietary models such as open source software licensing and open access to scientific literature.

There are also widespread perceptions in many sectors, ranging from disaffected teenagers to judges ${ }^{15}$ and elderly professors, of copyright as complex, inaccessible, productive of difficulty and uncertainty in relation to otherwise lawful activities, and sometimes absurd. About to watch the film Lost in Translation (possibly a very apt title in the circumstances), I heard a ripple of laughter pass through the audience in an Edinburgh cinema as a "short" by the Federation Against Copyright Theft warned us all in baleful fashion against trying to use our mobile phones or video cameras to take photographs or other images from what we were about to see. The prevalence of such derision for the law is

\footnotetext{
${ }_{14}^{14}$ Accessible at http://www.adelphicharter.org/.

${ }^{15}$ For whom see in particular H Laddie, 'Copyright: Over-strength, Overregulated, Over-rated?', [1996] 17 EIPR 253; R Jacob, 'The Onward March of Intellectual Property Rights and Remedies', in R Dreyfuss, D Zimmerman and ? First (eds), Expanding the Boundaries of Intellectual Property: Innovation Policy for the Knowledge Society (2001), 415.
} 
not helped by the further perception that copyright is in fact widely flaunted, whether deliberately or ignorantly, or, amongst those minded to comply if they can (such as academics), as a result of practical inability to find out whether copyright exists in a given piece of work and, if so, who its owner is.

A huge range of areas of activity is affected by copyright - government, entertainment, education, creativity, technology and international development, to name but a few. As the short list of major issues given above suggests, much of the current debate has arisen in the context of the ever-expanding scope and possibilities of digital, wireless and mobile technologies for the creation, dissemination and reproduction of ideas, information and entertainment. The ability to make material available so that it is potentially always accessible to users at times and places chosen by them, along with expanding possibilities of, and demand for, interactivity between suppliers and users, has transformed the context for policy thinking in the areas traditionally covered by copyright.

So the need for reform is apparent - but it is not necessarily the case that the "primary role" in developing this reform should be for industry. Indeed, as Jessica Litman has pointed out from the US experience of copyright law-making, real problems are inherent in an approach to reform taking the self-perceived needs of industry as paramount. In the spirit of creative commons, I simply quote 
in extenso the key relevant passages from her book Digital Copyright, published in $2001:^{16}$

About one hundred years ago, Congress got into the habit of revising copyright law by encouraging representatives of the industries affected by copyright to hash out among themselves what changes needed to be made and then present Congress with the text of appropriate legislation. By the 1920s, the process was sufficiently entrenched that whenever a member of Congress came up with a legislative proposal without going through the cumbersome prelegislative process of multiparty negotiation, the affected industries united to block the bill. Copyright bills passed only after private stakeholders agreed with one another on their substantive provisions. The pattern has continued to this day.

A process like this generates legislation with some predictable features. First of all, no affected party is going to agree to support a bill that leaves it worse off than it is under current law. ... Second, there's a premium on characterizing the state of current law to favour one's own position, since current law is the baseline against which proposals are negotiated. ... Third, the way these things tend to get settled in the real world is by

\footnotetext{
${ }^{16}$ Note that Litman had already set out much more detailed arguments on these issues in 'Copyright, Compromise and Legislative History' (1987) 72 Cornell LR 857 and 'Copyright Legislation and Technological Change' (1989) 68 Oregon LR 275. For a powerful review of Litman's book see Jane C Ginsburg 'Can Copyright Become User-Friendly?' (2001-2002) 25 Columbia-VLA J L \& Arts 71.
} 
specifying. ... As the entertainment and information markets have gotten more complicated, the copyright law has gotten longer, more specific, and harder to understand. ${ }^{17}$

Anyone who has grappled with the US Copyright Act will appreciate what Litman means. Later on, she elaborates her final point:

A process that relies upon negotiated bargains among industry representatives, however, is ill-suited to arrive at general flexible limitations. The dynamics of interindustry negotiations tend to encourage fact-specific solutions to interindustry disputes. The participants' frustration with the rapid aging of narrowly defined rights inspired them to collaborate in drafting rights more broadly but no comparable tendency emerged to inject breadth or flexibility into the provisions limiting those rights. ${ }^{18}$... If negotiated copyright statutes turn out to be so unworkable, why is it that Congress continues to rely on private interests to work out the text of bills? One reason may be ... [that] the participants are the people who will have to order their day-to-day business relations with one another around the provisions of the legislation. ... The process permits a give-and-take among a wide field of players whose competing interests are exceedingly complex.... Putting all of them into a room and asking them not to come out until they have agreed to be bound by the same

${ }_{17}^{17}$ Digital Copyright (2001), 23-25.

${ }^{18}$ lbid, 58. 
rules may be the most efficient approach to formulating law that will work well enough for each of them, although not necessarily for the rest of us. ${ }^{19}$

This last phrase leads Litman to her most potent objection to the reform process she is describing:

The need to balance concessions in order to achieve agreement, of course, imposes constraints on the sort of legislation that is likely to emerge from the process. Unless the participants become convinced that the new legislation gives them no fewer benefits than they currently enjoy, they are likely to press for additional concessions. It must therefore be expected that any successful copyright legislation will confer advantages on many of the interests involved in hammering it out, and that these advantages will probably come at some absent party's expense. ... It is the seeming inevitability of bias against absent interests, and of narrow compromises with no durability, that makes such a process so costly. Each time we rely on current stakeholders to agree on a statutory scheme they produce a scheme designed to protect themselves against the rest of us. Its rigidity leads to its breakdown: the statute's drafters have incorporated too few general principles to guide courts in effecting repairs. 20

${ }^{19}$ lbid, 61

${ }^{20} \mathrm{lbid}, 62$. 
Litman concludes:

Negotiations among current stakeholders tend to produce laws that resolve existing interindustry disputes with detailed and specific statutory language, which rapidly grows obsolete. Such laws consign the disputes of the future to resolution under models biased in favour of the status quo. A copyright law cannot make sensible provision for the growth of technology unless it incorporates both the flexibility to make adjustments and the general principles to guide courts in the directions those adjustments should take. The negotiation process that has dominated copyright revision throughout this century, however, is ill adapted to generate that flexibility. It cannot therefore be expected to produce statutes that improve with age. ${ }^{21}$

When I first read Litman's analysis, my initial reaction was that the history of copyright revision in the United Kingdom had been different. Each of the 1911, 1956 and 1988 Acts was preceded, not by a process of inter-industry bargaining, but by an independent committee or commission chaired by a relatively neutral figure such as an eminent judge, which heard and weighed evidence (of course often contentious in nature), and then made what appeared at least to be neutral and balanced assessments and recommendations, leading to wide-ranging overall legislation that tended to stand unaltered (but adaptably

\footnotetext{
${ }^{21}$ Ibid, 63. Ginsburg (note 16 above) describes Litman's conclusion on this point as "unassailable" (at 73).
} 
so) for periods of thirty to forty years. ${ }^{22}$ However, further reflection suggested that in the last decade of the twentieth century that kind of deliberative reform process had been displaced by a piecemeal, issue-driven approach within the European Union, which certainly came much closer to the US experience analysed by Litman. One thought, for example, of the succession of Directives each focused on relatively narrow aspects of copyright - Software, Rental Right, Term, Broadcasting, Databases, Artists' Resale Right, and the various topics covered in the Information Society Directive - and the often slow-moving, yet sometimes clamorous, debates, industry special pleading and lobbying, and often rather messy compromises (sometimes reached under political and time pressures) which led up to their eventual enactment.

The copyright Part of the Copyright, Designs and Patents Act 1988 as frequently amended and added to as a result of all these Directives now stretches to about 200 sections, to say nothing of various Regulations containing substantive provisions but not incorporated into the main Act. It is worth remembering, however, that, as originally presented, the 1988 Act got through most of the

\footnotetext{
${ }^{22}$ For the 1911 Act see the Gorell Report of the Committee on the Law of Copyright (Cd 4976,1909); for the 1956 Act, the Gregory Report on the Law of Copyright (Cmd 8662, 1952); and for the 1988 Act , the Whitford Report, Copyright and Designs Law (Cmnd 6732, 1977). John Gorell Barnes was President of the Probate Divorce and Admiralty Division of the High Court and was promoted to the House of Lords as Baron Gorell of Brampton in the same year as the publication of his copyright report. Sir Henry Stanley Gregory KCMG was an eminent civil servant. Mr Justice Whitford was for many years one of the Patent Judges in the Chancery Division of the High Court. Note also the Royal Commission on Copyright (C-2036, 1878), chaired initially by Lord Stanhope, a prominent Tory peer and historian, and, after his death in 1875, by Lord John Manners, the Postmaster-General in the then Conservative government.
} 
fundamental principles of copyright in about thirty, basically technology-neutral, sections, with the bulk of the remainder being made up of very fact- or sectorspecific exceptions, Copyright Tribunal rules, and criminal law and qualification provisions. Moral rights, which might be thought of as part of the fundamentals now ${ }^{23}$ were also found in this miscellaneous bundle of material; but since the 1988 Act was introducing the whole concept of moral rights for the first time in British copyright law, this inconspicuous position was not altogether surprising. The presentation of even the first thirty sections of the Act has, however, now become exceptionally messy thanks to their frequent adjustment in compliance with European Union requirements.

There is, then, a powerful argument, in the interest of letting people know what the law is in a matter affecting many aspects of everyday life, for producing a new but short Copyright Act stating the basic legal rules in an orderly, principled and accessible manner, leaving detailed regulation, where necessary, (e.g. specific exceptions for libraries, archives, the disabled, and public administration; or Copyright Tribunal jurisdiction and procedure; or the rules about qualification for protection), to statutory instruments (which should themselves nevertheless also be orderly, principled and accessible to those whom they affect). In all probability, such a short Copyright Act ought to be produced for the European Union, and not just for the United Kingdom. But there is no reason why the United Kingdom

${ }^{23}$ See further below, 000 . 
cannot take an initiative in this area, especially when the reforms in the air already envisage some form of European codification as an ultimate goal.

Such an initiative should not be undertaken, however, without careful preliminary consideration of the nature of the exercise upon which one is embarking. The remainder of this paper highlights two issues which would go to the heart of a recodification or restatement of copyright, namely the underlying fundamental policies or purposes of the law and the definition of the zone for copyright in relation to other forms of intellectual property right, and, indeed, to other rights such as exist under legislation about freedom of information and the reuse of public sector information (the problem of cumulation).

\section{B. THE PURPOSE(S) OF COPYRIGHT}

A fundamental question in thinking through systematic reform and codification is the purpose - or purposes - of copyright. Only with clear ideas of what we are trying to achieve will clear, coherent and principled law emerge.

\section{(1) Economic interests}

Copyright's economic purpose, the incentivisation and rewarding, in accordance with market demand, of those involved in the creation and publication of certain 
kinds of work, is traditionally emphasised in the United Kingdom. ${ }^{24}$ James

Purnell's speech in June 2005 shows that this idea is still dominant. In the European Union the rhetoric of the copyright reform process is also dominated by economic interests and the drive to complete the single market. These economic interests include, not only creators, but also entrepreneurs who convert what is created into products for the marketplace. Copyright is seen primarily as a response to market failure; without it, the expression of ideas and information, creativity and innovation would be available to all without reward for those who invested in the creation and dissemination of the works thereby produced.

However, the digital environment now raises the question whether the economic interests of the creator and entrepreneur, or of society, still actually require copyright. The technology allows the building into products - and also into the hardware needed to play the products - of digital rights management systems (DRMS) and technological protection measures (TPMs) that prevent unauthorised access and use unless and until such contractual conditions as the producer imposes (typically payment by way of credit card or fund transfer systems such as Paypal, and carefully restricted re-use), are met by the wouldbe user. Usually such DRMS are seen by critics hostile to current legal developments in the field as the manifestation of the worst of copyright, since

\footnotetext{
${ }^{24}$ There is a large number of economic studies of copyright, reaching a wide range of conclusions. A useful general survey is $\mathrm{W} R$ Cornish and D Llewelyn, Intellectual Property (5th edn, 2003), pp. 35-41, 373-380. Recent detailed works include R Towse (ed), Copyright and the Creative Industries (2002); W Landes and R Posner, The Economics of Intellectual Property Rights (2003); M Einhorn, Media, Technology and Copyright (2004).
} 
they can enable the prevention of use falling within the exceptions to copyright and indeed, the protection of works no longer or never in copyright. The position of the owner thus appears to be considerably strengthened at the expense of the user. ${ }^{25}$ Equally, however, through contracts such as the forms provided by Creative Commons, an author can indicate in advance, as it were, those uses of the work by others which are permitted, and require those using this method to apply those terms and conditions to further downstream sub-users. So in this context DRMS can operate in support of widespread use and later creativity with existing works. There is some evidence that in response to consumer demand right-owners are beginning to explore the possibilities of enabling consumers, through DRMS, to make use of their products other than simply playing them (for example, making additional copies to store on personal computers or playback machines). Further market pressures may lead to more such developments, particularly if different consumers might be prepared to pay variable prices for different packages of permissions made available through DRMS. Contract will therefore often be automated and "standard form" in this context, rather than the result of individual negotiation and bargaining; but none the less, given its enormous flexibility, can it replace copyright, and would that be a good thing? ${ }^{26}$

\footnotetext{
${ }^{25}$ L M C R Guibault, Copyright Limitations and Contracts (2002). See e.g. the decision of the Paris District Court, Perquin et UFC Que Choisir v SA Films Alain Sarde, Sté Universal Pictures Video France et al ("DVD Copy"), 30 April 2004, in which the use of TPMs to defeat the legislative permission for private copying was held legitimate; and further the commentary of Christophe Geiger, (2005) 36 IIC 148.

${ }^{26}$ There are of course issues about such matters as the equivalents to copyright term and exceptions in this model: these are dealt with below.
} 
An obvious tricky point is that it is copyright, for the most part, which, at least initially, creates the subject-matter around which contracting parties can subsequently bargain. In the absence of copyright at the point of creation there might be no room for bargaining at all. In particular, the individual author/creator without access to the means of sophisticated technological protection, dissemination and online payment methods would be at a serious disadvantage without copyright. One could of course try to create some sort of "fair contract" or "minimum terms" regime for such authors, perhaps akin in some way to the voluntary Code of Practice already operated in the United Kingdom by the Publishers Association, ${ }^{27}$ or to the German publishers' contract law found in that country's Copyright Act and significantly amended only in 2002. ${ }^{28}$ But these instruments assume the existence of copyright; and the "minimum contract" that would have to be created in the absence of copyright might end up looking remarkably similar to copyright.

Further, the economic interests protected by copyright are not limited to those of the author/creator of the work and the entrepreneur who first takes it to market. Since the economic rights protected by copyright are freely transferable to third parties, the person who at any given moment owns the copyright and reaps the economic returns it gives, may well be someone who had no hand in

\footnotetext{
${ }^{27}$ Accessible at the Publishers Association website, http://www.publishers.org.uk/paweb/paweb.nsf/pubframe!Open. See further Cornish and Llewelyn, Intellectual Property (5 ${ }^{\text {th }}$ edn, 2003), 486-7.

${ }^{28}$ See discussion in W R Cornish 'The Author as Risk-Taker' (2002-2003) 26 Columbia-VLA J L \& Arts 1.
} 
the original production of the work or the product flowing from it. How far such investors may deserve the same level of protection as the originators of the work is a nice question: after all, they are risk-takers to a greater extent than those from whom they bought the rights, and they have helped to ensure that the author/creator/first producer does indeed earn reward from their work. We could of course ban outright transfers of copyright, ${ }^{29}$ but licensing would still be necessary to secure the author's reward; while a licensee would certainly require some incentive in its own right to make the investment in a licence worthwhile.

Another economic interest is that of the employer whose employees create copyright works in the course of their employment, and who under United Kingdom law (but not other Continental laws) gets first ownership of the resulting copyrights. Given that the employer is an investor who is backing the production of copyright works, his gaining the copyright (at least in its economic aspects) and the return therefrom does not seem so dreadful as sometimes suggested by those from systems more focused on copyright as reflecting more of personality rights than economic interests. ${ }^{30}$

\section{(2) Personality and cultural interests}

Even in the United Kingdom, however, copyright's purposes are not limited to the protection and advancement of economic interests. The cultural dimension to

\footnotetext{
${ }^{29}$ As with moral rights: see below, 000 .

${ }^{30}$ Compare the Software Directive art 2(3). with the Database Directive arts 4 and 11.
} 
copyright is apparent in the nature of what it protects - literary, dramatic, musical and artistic works, films, sound recordings and broadcasts - and in the length of time for which it gives that protection, which is not necessarily (or at all) driven by economic analysis. More subtly, the variable term as between author and media works also reflects cultural judgments, giving a higher value to "pure" authorship than to exploitation of technology. In any event, it is clear that the length of protection considerably exceeds what is needed to incentivise authors and producers, and that most works will have an economic life considerably shorter than their copyright terms.

But copyright's cultural purpose is most evident in the moral rights. These recognise inalienable, non-economic interests that an author (but no-one else) may continue to exercise in respect of a work even though no longer owner of the copyright or of the physical form in which the work was first created and recorded. There are two major rights recognised in the present United Kingdom law, ${ }^{31}$ as follows:

- Paternity ${ }^{32}$ : the right to be identified as author of a literary, dramatic, musical or artistic work, or as director of a copyright film;

\footnotetext{
${ }^{31}$ See below, 000, for the prospective introduction of artists' resale rights from 1 January 2006.

${ }^{32}$ In a world of gender neutrality this right might be better re-named the attribution right. But gender neutrality is not always well understood in nonAnglophone parts of the world.
} 
- Integrity: the right of such authors and directors to prevent derogatory treatment of their work;

Inalienability means that these rights cannot be the subject of commerce in themselves; but under United Kingdom law, they may be waived, albeit this requires writing. Further, the paternity right must be "asserted" before it can apply, and it is not generally available to authors whose works are created in the course of employment. ${ }^{33}$ In these ways, British moral rights are weaker than the systems found, for example, in some other EU member states.

The Commission working paper, however, consistently with the emphasis generally placed on the economic in European reforms, sees "no apparent need to harmonise moral rights protection at this stage". ${ }^{34}$ TRIPS and the WCT, the most recent harmonising instruments at a global level, make no mention of moral rights, and the subject is in general underplayed in international negotiations. Yet in the continental European legal tradition, at least, moral rights are plainly an important aspect of copyright, protecting significant interests. David Vaver has argued that a strong moral rights regime is in the public interest, on the following grounds:

- A trade mark-like function of assuring the public as to the origin and quality of the work

${ }^{33}$ For all this see Copyright Designs and Patents Act 1988, Part 1 Chapter IV.

${ }^{34}$ Above, note 1, para 3.5. 
- Social reward going to where it belongs

- Cultural preservation, helping maintain the record of the country's culture

- Author empowerment in connection with the exploitation of their work. ${ }^{35}$

The rights may be considered particularly significant in an online world where works can be speedily and endlessly transmitted and retransmitted, readily modified and re-shaped, and integrated, in whole or in part, in other works. Even if economic interests in the digital environment can be as effectively defended by way of contract as by copyright, it is much less clear that this is so with the moral rights, since it will not necessarily be the author who is making the product available to the public (contractually or otherwise).

A further argument draws on the link between moral rights and fundamental human rights which underlie many personality rights in general. Human rights to dignity and respect seem particularly apt to support the right to be identified in connection with one's work and to have that work treated appropriately by others. ${ }^{36}$ Many of the functions of moral rights identified by

\footnotetext{
35 'Moral Rights Yesterday, Today and Tomorrow', (1999) 7 Intl J of Law and Information Technology 270.

${ }^{36}$ See further on this theme two papers by Mira T Sundara Rajan: 'Moral Rights in the Digital Age: New Possibilities for the Democratization of Culture' (2002) 16 Intl Rev of Law Computers \& Technology 187; 'Moral Rights in Information Technology: a New Kind of "Personal Right”?' ((2004) 12 Intl J of Law and Information Technology 32; also Leslie Kim Treiger-Bar-Am, 'The Moral Right of
} 
Vaver could also be of great importance in a world of open access journal publishing, and after much debate they are recognised in the Creative Commons UK licences for England \& Wales and Scotland.

The issue here is, then, whether in a codification or reform process moral rights should be given increased recognition as of especial significance in the digital environment. The European Commission appears to think not, as the 2004 staff working paper says that "no evidence exists in the digital environment either that the current state of affairs does affect the good functioning of the Internal Market". ${ }^{37}$ But, as we have been arguing, the good functioning of the Internal Market is not the only relevant consideration in the reform and restatement of copyright in Europe.

If such arguments are accepted, then also questions may follow about the present United Kingdom regime, in particular the position with regard to

- employment under the paternity right;

- the need to assert paternity right;

- regulation of waivers for unconscionability;

- duration - it is not clear, especially in the light of some of the underlying policies referred to above, why there should be a time

Integrity: a Freedom of Expression', in F Macmillan (ed), New Directions in Copyright Law vol 2 (forthcoming 2006).

${ }^{37}$ Above note 1, para 3.5 . 
limitation on any of the moral rights; on the other hand, moral rights which endure beyond an author's lifetime may be an undue limitation of the public domain, putting powers capable of amounting to censorship in the hands of persons other than the one in whose interest the rights were created;

- the name of the rights, at least in the UK, where 'moral' in the context of rights tends to suggest, at least to the uninformed, 'not legal', and so to devalue their significance; 'author's personality rights', while cumbersome, might better convey what the law seeks to protect here.

The United Kingdom will introduce artists' resale rights (droit de suite) in 2006, following a harmonising Directive in $2001 .^{38}$ This will guarantee the original artist a share of the returns being earned from sales of the original art work, regardless of whether the artist still owns the copyright in the work in question. While arguably this is more an economic than a moral right, making it legitimate to take account of the potential economic as well as cultural impact of doing so, it may also be for consideration whether the underlying principle is capable of extension to other areas. For example, if the employer is the first owner of the economic rights of copyright in works produced by employees in the course of their employment, is there a case for guaranteeing to the employee a right to participate in the economic benefit which the work brings to the

${ }^{38}$ Parliament and Council Directive 2001/84/EC on the resale right for the benefit of the author of an original work of art. 
employer? An analogy can also be drawn with employee rights in patent law, ${ }^{39}$ although that scheme does not appear to have been regularly used and is not

easy to apply. ${ }^{40}$ However, this may also be because well-advised employers put in place suitable or satisfactory schemes of their own devising as part of the contract of employment. Were an employee reward scheme to be introduced into copyright, the question of whether it should be a default scheme subject to contract would have to be addressed.

\section{(3) Non-producer interests}

Our focus to date has been on the producer side of the copyright equation, or in the consideration of what the present law seeks to protect by conferring rights. But by placing various limitations upon what it protects on the producer side, copyright also protects, directly or indirectly, other interests which here we may most simply describe as "non-producer" in nature. Thus -

- Freedom of expression and information are protected by the limitation of copyright to forms of expression, as distinct from the ideas and information which are expressed

- Copyright is not unlimited in duration, and works which fall out of copyright at the end of their term are available to all for any purpose

${ }^{39}$ Patents Act 1977 ss 39-43.

40 L Bently and B Sherman, Intellectual Property Law (2 ${ }^{\text {nd }}$ edn, 2004), 567-72. 
- Works which fall below the threshold requirement of "originality" do not have copyright, even if in other respects they come within one of the categories of protected work (e.g. being written, they are literary).

- Works which do not fit into the expressed categories of the law do not receive copyright protection (e.g. the format and catchphrases of the TV show "Opportunity Knocks" did not amount to a dramatic work and so did not receive copyright protection ${ }^{41}$ )

- The copyright exceptions, whether general - e.g. fair dealing for private study, non-commercial research, or news reporting - or for specific types of work - e.g. decompilation of computer programs, "time-shifting" of TV broadcasts - reflect a recognition that certain non-producer interests outweigh producer ones in at least some circumstances; or at any rate the impracticability of certain kinds of copyright enforcement.

- The product embodying the protected work can generally be dealt with freely by the first and subsequent purchasers apart from integrity / commercial rental / lending rights.

Cumulatively, these aspects of the law amount to what is often called the "public domain". The advantage of a copyright law over a contractual regime is that it gives the notion of "public domain" some genuine consistency and coherence. But in some ways "public domain" is an unhelpful phrase, since it can also be

${ }^{41}$ Green v Broadcasting Corp of New Zealand [1989] 2 All ER 1056 (PC). This case led to attempts to procure legislative provision protecting such "formats" (so far unsuccessful). 
applied without abuse of language or law to material which is simply published or publicly available, whether or not it is also in copyright, and whether or not the user has to pay for its use. In thinking through the purposes served by copyright, however, the scope of the area which copyright does not reach, and the reasons (if any) why it does not do so, need to be part of the discussion and carefully weighed in the overall balance. Thus, for example, we need to address the argument that copyright exceptions exist principally to deal with market failures, areas of activity in which the creation of an efficient market where producers and users could bargain effectively seemed impossible or far too expensive; and that the Internet now provides the solution with hugely reduced transaction costs, making exceptions un-necessary. ${ }^{42}$ In opaque and rather unsatisfactory fashion the Information Society Directive has tried to point a way forward for the time being, by granting member states the power to ensure that DRMS are not used to prevent those with lawful access to a copyright work from having the benefit of copyright exceptions and limitations. ${ }^{43}$ It remains to be seen how effectively this power will be wielded, and whether the underlying principle can also be applied to prevent DRMS cutting off access to, and use of, out-of-copyright and other public domain material; but its existence is at least recognition that rights are not absolute, and that other interests are in play.

\section{(4) Conclusion}

${ }^{42}$ See e.g. Tom W Bell, 'Fair Use vs. Fared Use: the Impact of Automated Rights Management on Copyright's Fair Use Doctrine' (1998) 76 North Carolina LR 557. ${ }^{43}$ European Parliament and Council Directive 2001/29/EC, art 6(4). 
To summarise the arguments of this section of the paper: the reform and possible codification of copyright needs to take account of all the interests involved in the law, and not simply the economic ones which seem to be in the forefront of official thinking, important and powerful though those are. In particular there is a need to engage with the personality- and culture-related claims of individual creators, and to recognise that the limitations hitherto placed upon copyright have served interests which are also important to the economic and cultural wellbeing of society as a whole. The status quo is not necessarily where we wish to remain; but it provides the platform upon which we should seek to build.

\section{CUMULATION ISSUES}

Copyright sits alongside other forms of intellectual property right and the same subject matter can be potentially the subject of two or more rights. A codification of copyright has to decide how to address this problem. Should there be a rigorous scheme of one subject-matter, one right; or should overlap be permitted, and if so, to what extent, since the overlapping rights may in fact be contradictory, either as a matter of substance or in terms of the policies being pursued through the two regimes? Similar questions arise inside copyright itself, since it categorises different kinds of work in order (usually) to grant them different kinds of right.

\section{(1) Copyright and other intellectual property rights}


The facts that copyright comes into existence with the relevant work (including possibly when the work is still in process of completion), and that as a result of the Berne Convention it takes a potentially world-wide effect for 50 years or more, but without any immediately necessary extra costs, makes it an enormously attractive right for investors of all kinds in new works. Thus at points where copyright may overlap with other forms of intellectual property, particularly where the other form requires registration, with its attendant costs (e.g. patents, trade marks, registered designs), the would-be right-owner may well be tempted to prefer copyright; and where a court sees a deserving producer being "ripped off" by a copyist, copyright may be the readiest tool at hand with which to tackle the problem. "What is worth copying is worth protecting." ${ }^{44}$

Cornish has remarked upon "a fundamental difference of attitude" towards the cumulation problem: either intellectual property rights are to be seen as a set of specific exceptions to a general freedom of action and competition, in which case cumulation needs to be tackled and eliminated where possible; or intellectual property is a general protection for innovators against free riders, and the cumulation of rights is simply a useful additional weapon for the right-holder in that ongoing struggle. ${ }^{45}$ But, whichever view is taken in general, difficulties have undoubtedly resulted on occasion at least from too great willingness to resort to copyright and consequent potential overlaps of protection with other

${ }^{44}$ University of London Press v University Tutorial Press [1916] 2 Ch 601 at 610 (per Peterson J)

45 'Cumulation and Convergence of Intellectual Property Rights', in P Mirfield and R Smith (eds), Essays for Colin Tapper (2003), 204. 
forms of intellectual property. The best-known example is the development of copyright in the field of industrial design between 1965 and 1985, as a result of which the policy of design law became badly distorted. This was put right (more or less) by the Copyright Designs and Patents Act 1988, which sought, with some success, to expel copyright from the domain of product design. ${ }^{46}$ Again, protection for single words, titles, catchphrases, computer menu commands and the like might have caused the courts less unease with a firm approach that these were protectable, if at all, only as trade marks, or by the law of passing off. $^{47}$

Current issues in this area involve computer programs, databases and, once more, industrial designs.

With computer programs, copyright is the principal form of intellectual property protection; but patents, having been excluded from computer programs "as such", have been granted for computer programs if they have technical effects (whatever that may be decided to mean). The proposed Directive on the patentability of computer-implemented inventions, intended to "clarify" the law in this area, has now been decisively rejected by the European Parliament, ${ }^{48}$ but

\footnotetext{
${ }^{46}$ The history is explained in H L MacQueen, Copyright, Competition and Industrial Design ( $2^{\text {nd }}$ edn, 1995).

${ }^{47}$ See e.g. Exxon Corporation v Exxon Insurance Consultants International Ltd [1982] Ch 119; Powerflex Services Pty Ltd v Data Access Corporation [1999] HCA 49.

${ }^{48}$ See http://www.europarl.eu.int/news/public/focus_page/057-1002-255-9-37909-20050819FCS01001-12-09-2005-2005/default_en.htm.
} 
further fresh proposals can be expected from the Commission in the not too distant future. It is clear that software patent monopolies have the potential to run into conflict with software copyright rules, in particular the rules established by the Software Directive allowing for such actions as making back-up copies and decompilation to achieve interoperability between an independently created program and other programs. ${ }^{49}$ These copyright rules are not readily compatible with patent exceptions permitting private acts for non-commercial purposes or acts for experimental purposes relating to the subject-matter of the invention. ${ }^{50}$

Recital 22 of the now rejected Software Patents Directive, as set out in the Common Position of the Council in November 2004, said:

The rights conferred by patents granted for inventions within the scope of this Directive should not affect acts permitted under Articles 5 and 6 of Directive 91/250/EEC, in particular under the provisions thereof in respect of decompilation and interoperability. In particular, acts which, under Articles 5 and 6 of Directive 91/250/EEC, do not require authorisation of the rightholder with respect to the rightholder's copyrights in or pertaining to a computer program, and which, but for those Articles, would require such authorisation, should not require authorisation of the rightholder with respect to the rightholder's patent rights in or pertaining to the computer program.

${ }^{49}$ Council Directive 91/250/EC, arts 5 and 6.

${ }^{50}$ Patents Act 1977 s 60(5). 
This was then given effect in draft Article 6:

Relationship with Directive 91/250/EEC

The rights conferred by patents granted for inventions within the scope of this Directive shall not affect acts permitted under Articles 5 and 6 of Directive 91/250/EEC in particular under the provisions thereof in respect of decompilation and interoperability.

While the draft Directive thus awkwardly provided for a form of cohabitation between patent rights and copyright exceptions, it did not address the much more fundamental question of whether dual protection should be allowed at all. Some discomfort over this was part of why the Directive fell foul of the parliamentarians in Strasbourg.

With databases the issue is one created by the Database Directive $1996 .^{51}$ Under it, a database may be protected by copyright if its selection and arrangement constitute an intellectual creation (a super-originality test). ${ }^{52}$ The Database Directive also introduced an additional, sui generis database right to protect those commercially valuable and expensively created databases henceforth to be excluded from copyright by the higher originality requirement. The principal ground for database right protection is the creator's substantial investment in obtaining, verifying or preserving the contents of the database, and it is immaterial whether or not the database is also a copyright work, i.e. is an

\footnotetext{
${ }^{51}$ European Parliament and Council Directive 96/9/EC.

52 Ibid, art 3(1).
} 
intellectual creation of the compiler in its selection or arrangement. ${ }^{53}$ But a copyright database is not precluded from also enjoying database right, the relevance of this being that database right confers protection against extraction and re-utilisation of the contents of the database (i.e. the information in it), rather than the copyright protection for the structure of the contents. ${ }^{54}$ Further, as the Commission's 2004 working paper acknowledges, the differences between the copyright and the sui generis exceptions may mean that the former can be undermined by the rights existing under the latter. ${ }^{55}$ At the least there appears to be a recipe for confusion in the present law. Once again, the question of the desirability of dual protection arises.

The problem with industrial designs arises first because the Designs Directive $1998^{56}$ and Community Designs Regulation $2001^{57}$ greatly expanded the concept of a registrable design by comparison with the previous United Kingdom law. Two-dimensional items, such as graphic symbols, became products in their

${ }^{53} \mathrm{lbid}$, art 7.

${ }^{54}$ See Database Directive arts 3, 5, 7. See further on the apparently limited protection conferred by the sui generis right the decisions of the European Court of Justice: Case C-46/02 Fixtures Marketing Ltd v Oy Veikkaus AB [2004] ECR I10365; Case-C 203/02 British Horseracing Board v William Hill Organization Ltd Case [2004] ECR I-10415; Case C-338/02 Fixtures Marketing Ltd v Svenska Spel AB [2004] ECR I-10497; and Case C-444/02 Fixtures Marketing Ltd v OPAP [2004] ECR I-10549; and the aftermath of the BHB v Hill case in the Court of Appeal, reported at [2005] RPC 35.

${ }^{55}$ Above, note 1, para 2.1.3.2. See also the Report of the Royal Society (London), Keeping Science Open (2003), chapter 5 (accessible at http://www.royalsoc.ac.uk/policy (click on 'Policy statement and reports', then on '2003').

${ }^{56}$ European Parliament and Council Directive 98/71/EC.

${ }^{57}$ Council Regulation (EC) No 6/2002. 
own right alongside the more traditional three-dimensional kind ${ }^{58}$ While graphic design could have claimed protection under the old United Kingdom law as pattern or ornamentation if applied to a three-dimensional product, registration was denied to items of a primarily literary or artistic character where the article was no more than a carrier for the design. Copyright was expected to provide the necessary protection. So the pattern of words and lines on a football pools coupon was not a registrable design, since the paper which constituted the article to which the design was applied had no function other than to carry the design. ${ }^{59}$ The result would now be different, even although the pools coupon also has copyright. ${ }^{60}$ On the other hand the design applied to wallpaper, curtains, chair covers or bed linen would have been registrable under the old law and continues to be so now; it also has copyright. ${ }^{61}$

Similar overlaps can arise with three-dimensional products within the scope of artistic copyright, such as sculptures, works of artistic craftsmanship and, perhaps most significant of all, works of architecture. The indeterminate word "item" which appears in the definition of "product" in the new law certainly does not by itself limit the concept to goods or corporeal moveables. Sculptures (but not works of artistic craftsmanship) were definitely excluded from registration

${ }^{58}$ Designs Directive, art 1(b); Community Designs Regulation, art 3(b). Note that computer programs are specifically excluded from the definition of "product", so they are not eligible for a third form of IP protection. But there are questions about whether, for example, screen displays are caught by the exclusion.

${ }^{59}$ Littlewood's Pools Ltd's Application (1949) 66 RPC 309.

${ }^{60}$ Ladbroke (Football) Ltd v William Hill (Football)Ltd [1964] 1 WLR 273 (HL).

${ }^{61}$ See e.g. Designers Guild Ltd v Russell Williams (Textiles) Ltd [2001] FSR 11 $(\mathrm{HL})$ (fabric designs). 
under the old law, but seem to epitomise a work of "handicraft" which can be protected under the new law.

The cumulation problems at the copyright/registered designs interface are addressed with in the United Kingdom legislation: first, by excluding copyright as far as possible; and, second, where copyright cannot be excluded, by aligning its results with those of registered designs law, again so far as possible. ${ }^{62}$ In simplified terms, making an article to the design or copying another article made to the design is not an infringement of copyright; such production of articles is to be regulated under designs law. There is still difficulty: to have copyright the design must be embodied in a design document or model, and for these purposes design is defined as merely "any aspect of the shape or configuration (whether internal or external) of the whole or part of an article, other than surface decoration". ${ }^{63}$ But, as discussed above, registered designs protection now reaches beyond three-dimensional shape or configuration, and it is therefore arguable that design features which are registered but which are not shape and configuration still also have full artistic copyright, even against three-dimensional reproduction. ${ }^{64}$ But the United Kingdom legislation has a failsafe at this point: if

62 See generally Copyright Designs and Patents Act 1988, ss 51-53; Copyright (Industrial Process and Excluded Articles) (No 2) Order 1989 (SI 1989/1070). 63 Ibid, s 51 (3).

${ }^{64}$ See further on this Lambretta Clothing Co Ltd v Teddy Smith (UK) Ltd [2005] RPC 6 (CA), an unregistered design right case where a similar question had to be addressed. A claim to full artistic copyright in the "trackways" of colouring in a retro track top (which had been denied unregistered design right because not shape or configuration) was also denied. Mance LJ dissented on a reading of the statute which is persuasive to this reader, at least; but Jacob and Sedley LJJ took 
non-shape/configuration features of a registered design are exploited, by or with the licence of the copyright owner, by making articles commercially, then the copyright period will not run for the usual author's lifetime plus 70 years. Instead the copyright so far as concerns making articles to that design will expire 25 years after the first marketing of such articles, that is, at the end of a period equivalent to the maximum time for protection under the registration system. ${ }^{65}$ If, on the other hand, the infringing exploitation is non-commercial, registered designs law would not avail its owner in such circumstances, and copyright can be given its head.

The general issue here appears to be one of basic policy with regard to cumulation: are overlapping rights to be avoided or not? Should there be a general provision - or at least a presumption - in intellectual property law that a claim to one form of protection (whether at registration stage or in infringement proceedings in court) precludes any other form of protection for the work in question, at least if the claim is successful? The immediate impact of this would be with regard to the development of a new Software Patent Directive, and the review of the Database Directive. With regard to the latter, it would also raise the question of whether databases should be protected by copyright OR by a sui generis right, and if the latter, how, if at all, that should be reformulated. ${ }^{66}$ Or is

what they regarded as the common sense position, whatever the statute might say.

${ }^{65}$ Copyright Designs and Patents Act 1988, s 52.

${ }^{66}$ Note the Commission's Communication, Evaluation of Directive 96/9/EC on the Legal Protection of Databases Brussels 9.8.2005, which suggests that the sui 
cumulation inevitable? It certainly appears to be so in the context of design protection, ${ }^{67}$ but this leads to tortuous law designed to keep the two apart and, so far as this cannot be done, in line with each other. It is not a pretty sight.

\section{(2) Cumulation within copyright}

There are also issues of cumulation within copyright itself. Many products in the copyright domain are likely to enjoy more than one copyright, often with each one having a different owner. Thus a book will have copyright as a literary work, but there will also be a copyright in its typographical arrangement, as would also be the case with printed dramatic scripts and musical scores. A database has copyright in the selection and arrangement of its contents, but this does not affect any copyright that items of content may have in their own right. A sound recording of a piece of music will involve copyrights, not only in the sound recording as such, but also, separately, one in the music. And if the work recorded is a song, there will be a further copyright in the song lyrics. ${ }^{68}$ A broadcast of a film or sound recording will have copyright as a broadcast, but this will leave unaffected the

generis right has failed to achieve its objective of boosting the global competitiveness of the European database industry (although the UK continues to be the leading member state in the field). It is understood that abolition of the right is one of the options under consideration by the Commission, along with revision of the Directive, or doing nothing, simply awaiting further judicial decisions (the last being the likeliest outcome)

${ }^{67}$ Unless separate design protection was abolished altogether, which seems most unlikely.

${ }^{68}$ There are also performers' rights to be considered, increasingly similar to copyright in content. In some contexts, such as popular music, the performer's contribution may be much more important to the success of a work than the composer of the music or the lyricist. 
copyrights in the film or sound recording. While the sound track accompanying a film is treated as part of the film for copyright purposes, a copyright may also subsist in the sound track as a sound recording.

The difficulty which arises from this is the variability of the copyrights which may exist in a product, meaning that while one element is in the public domain, another is not. This could have the undesirable effects of damaging the remaining copyright interest in the work in question; or inhibiting its appropriate free use; or simply confusing people. The issue was focused in the summer of 2004 by the debate about the copyright term in sound recordings. While the right in recordings made in, say, 1954 would expire from 1 January 2005, the rights in the recorded music and song lyrics would continue until 70 years after the deaths of the respective authors. There was thus no danger at all of a rash of unauthorised issues of copies of old recordings, since that would also involve copying and issuing to the public works that were still in copyright (further, copyrights that presumably would often be held by the recording companies rather than the original authors). A question of policy may therefore be whether, when a product enjoys multiple copyrights, these ought to stand and fall together, at least in relation to products of the kind in question; and this, whatever the duration of the rights may finally be. ${ }^{69}$

\footnotetext{
${ }^{69}$ Note also the Commission 2004 working paper (above note 1), para 2.2.3.2, on "Criteria for calculating the term of protection in the musical sector", observing that some member states treat songs as works of joint authorship between lyricist and composer, others (including the UK) as two distinct works with different authors; meaning that the copyright term is very variable in the EU. The
} 
In a number of recent cases the English courts have held that a work may belong to more than one of the categories into which works are divided in the copyright legislation. So, for example, electronic circuit diagrams have been held to be both literary and artistic works, ${ }^{70}$ while a film has been held to be also a dramatic work. ${ }^{71}$ As Laddie $\mathrm{J}$ has observed, this is a different point from the one that a single product may embody several copyrights:

[A]lthough different copyrights can protect simultaneously a particular product and an author can produce more than one copyright work during the course of a single episode of creative effort, for example a competent musician may write the words and the music for a song at the same time, it is quite another thing to say that a single piece of work by an author gives rise to two or more copyrights in respect of the same creative effort. In some cases the borderline between one category of copyright work and another may be difficult to define, but that does not justify giving to the author protection in both categories. The categories of copyright work are, to some extent, arbitrarily defined. In the case of a borderline work, I think

paper raises the possibility that the term for such works as a whole should always be calculated in relation to the last-surviving author.

${ }^{70}$ Anacon Corp Ltd v Environmental Research Technology Ltd [1994] FSR 659; Electronic Techniques (Anglia) Ltd $v$ Critchley Components Ltd [1997] FSR 401; Sandman $v$ Panasonic UK Ltd [1998] FSR 651. Note that there is also a cumulation problem here involving UK unregistered design right, which has been (controversially) held applicable to electronic circuit diagrams: Mackie Designs v Behringer Specialised Studio Equipment (UK) Ltd [1999] RPC 717.

${ }^{71}$ Norowzian v Arks Ltd (No 2) [2000] FSR 363. 
there are compelling arguments that the author must be confined to one or other of the possible categories. The proper category is that which most nearly suits the characteristics of the work in issue. ${ }^{72}$

From a taxonomic point of view there must be much to be said for this approach; what after all is the point of having categories in law if they are not mutually exclusive? And if they are not mutually exclusive, or fail to capture particular types of work adequately, should the categorisation not be abandoned or re-thought? Thus, for example, the Berne Convention requires protection of "literary and artistic work", ${ }^{73}$ which includes "every production in the literary, scientific and artistic domain, whatever may be the mode or form of its expression"; ${ }^{74}$ this is followed by an illustrative list, while elsewhere, and only so to speak incidentally, the Convention refers to dramatic, musical and cinematographic works. ${ }^{75}$ French law speaks of "works of the mind whatever their kind, form of expression, merit or purpose" and gives thereafter an illustrative list. ${ }^{76}$ The principle of Occam's razor might usefully be applied: categories are not to be multiplied un-necessarily in copyright law, and perhaps the present United Kingdom statute is guilty of that offence.

\footnotetext{
${ }^{72}$ Electronic Techniques (Anglia) Ltd v Critchley Components Ltd [1997] FSR 401, 413.

${ }^{73}$ Berne Convention, art 1.

${ }_{75}^{74} \mathrm{lbid}$, art 2.1.

${ }^{75} \mathrm{lbid}$, arts 4, 11, 13 and 14bis.

${ }^{76}$ Intellectual Property Code Art L 112-1, 2. More specific provision has to be made for the neighbouring rights of performers, and producers of phonograms, videograms and audiovisual communications (see Book II).
} 


\section{CONCLUSIONS}

I want to conclude this paper with some comments on the potential for an academic contribution to the process of reform and possible codification with which I began. That contribution need not be confined to the fairly high-level questions to which I have been addressing myself. Nor need it limit itself to comment on the policy and other issues on which much further detailed research is required.

A model for possible work which I have in mind is drawn from experience over the last 25 years in the field of contract law. In 1980 the Vienna Convention on the International Sale of Goods (CISG) was concluded. It dealt with many but by no means all issues of contract law. Academics throughout Europe have spent much of the ensuing quarter-century in developing and completing systems of contract law on the basis of CISG, structured rather in the manner of codes or restatements on the US model. The best-known of these, in which I was involved myself as the Scottish representative from 1995, was the Commission on European Contract Law headed by Professor Ole Lando of Denmark. In 2003 the Commission finally published the complete Principles of European Contract Law (PECL) ${ }^{77}$ Four years before, the Lando Commission had in effect given birth to the Study Group on a European Civil Code, which has since been working in the same way on a number of other areas of private law such as

\footnotetext{
${ }^{77}$ Published by Kluwer in two volumes constituting (1) Parts I and II and (2) Part III. For the texts see http://frontpage.cbs.dk/law/commission_on_european_contract_law/index.html.
} 
sales, services contracts, tort, unjustified enrichment and trusts. The first fruits of its work will be published in 2005 or 2006, and the project in its current form was due to be completed in $2007 .{ }^{78}$

Now, however, what seemed to be an entirely academic venture, albeit one which had the hope that it might some day influence legal development in the European Union, has become something much more significant. In July 2001 the European Commission issued a Communication to the Council and the European Parliament on European Contract Law ${ }^{79}$ seeking views on whether problems result from divergences in contract law between Member States and whether the proper functioning of the Internal Market might be hindered by problems in relation to the conclusion, interpretation and application of crossborder contracts. The Commission was also interested in whether different national contract laws discourage or increase the costs of cross-border transactions. If concrete problems were identified, the Commission also wanted views on possible solutions, such as -

- leaving it to the market;

- promotion of the development of non-binding contract law principles such as the Principles of European Contract Law;

${ }^{78}$ See the Study Group's website, http://www.sgecc.net/. The series, entitled Principles of European Law, will be published by Sellier.

${ }^{79} \operatorname{COM}(2001) 398$ final. 
- review and improvement of existing EC legislation (the acquis) in the area to make it more coherent and/or adaptable;

- adoption of a European contract code at EC level.

In February 2003 the Commission issued a further Communication to the European Parliament and Council entitled A More Coherent European Contract Law: An Action Plan. ${ }^{80}$ The Communication suggested a mix of non-regulatory and regulatory measures in order to solve the problems identified by its previous consultation, including -

- increasing the coherence of the Community acquis in contract law by means of what was called a Common Frame of Reference (CFR) for contract law;

- promoting the elaboration of EU-wide general contract terms;

- examining further whether problems in European contract law require non-sector-specific solutions such as an optional instrument on the subject.

A further Communication from the Commission to the European Parliament and Council, entitled European Contract Law and the revision of the acquis: the way forward was published in October $2004 .^{81}$ The proposal for the development of a CFR is to be taken forward as a means of improving the quality

${ }^{80} \mathrm{COM}(2003) 68$ final.

${ }^{81}$ COM (2004) 651 final. 
and consistency of the acquis in the area of contract law. The CFR is seen as a toolbox towards improvement of the quality and coherence of the acquis and future legislation, as well as its simplification. "The CFR will provide clear definitions of legal terms, fundamental principles and coherent model rules of contract law, drawing on the EC acquis and on best solutions found in Member

States' legal orders" ${ }^{82}$ It will however be a non-binding instrument, although the Commission reserved the right to consult again on this question when elaborating the CFR. The promotion of EU-wide standard terms and conditions is to be taken forward via a website which will be a platform for the exchange of information on such terms and conditions. Further, and in parallel with the development of the CFR, the Commission will continue to investigate the opportuneness of a non-sectoral-specific optional instrument on European contract law.

In June 2005 the Commission contracted under the Sixth Framework programme with a number of groups, to carry out the research needed for the preparation and elaboration of the CFR by 2007. The groups involved, known collectively as the CoPECL-Network of Excellence, include the Study Group on a European Civil Code and the Research Group on the Existing EC Private Law (the Acquis Group). Most of the Network groups are university-based. In order therefore to avoid the reproach of being merely an academic exercise, the work of the groups is being discussed and criticised in "stakeholder workshops" over

82 Ibid, para 2.1.1. 
the study period, the stakeholders including representatives of business, consumers and legal practice. The overall aim will be to adopt a tried and tested CFR by 2009.

What can be seen here is a set of academic projects which set out to influence the law, not as marginal critics on the sidelines, but as proponents of well developed alternative models; and which were available when the critical moment arrived and the Commission began to take the idea of a European contract law seriously. The Commission has evidently already begun to take a European copyright law seriously, so academic copyright lawyers may not have the luxury of the time that by chance was afforded to their contract colleagues. But copyright projects akin to the Lando Contract Commission and the Study Group on a European Civil Code are not unthinkable and would probably not need so much time, given the amount of research and knowledge that has already gone into comparative copyright law in Europe as a result of the various Directives on different aspects of the subject. There are models that can be followed, therefore, and opportunity exists in the form of the Seventh Framework programme. It is up to us now to seize the day. 